\title{
BUILDING A MUTUALISTIC RELATIONSHIP MARKETING TO MEDIATE BETWEEN THE COMPETENCE OF SERVICE TO THE COMPANY'S PERFORMANCE
}

\author{
Marsudi \\ Faculty of Economics and Business, University of Muhammadiyah Malang, Indonesia \\ Email: marsudiudik@yahoo.com
}

\begin{abstract}
This study develops a new theoretical approach to solve differences between customer service competence and firm performance. This new concept is called mutuality collegiate relation. Mutuality collegiate relation is established from relational interaction, belief, intimacy, and equality of power. It is then related and tested its relationship with firm performance. Variables in this research include transactional service competence, after sales service competence, and customer retention program. Empirical data is collected by distributing questionnaires to 105 active shariah micro financial institutions in East Java, Indonesia. The sampling method is a purposive sampling technique. The study shows that seven of nine hypotheses are accepted while the remaining two hypotheses are rejected. By using the structural equation modeling procedure, these results conclude that mutuality collegiate relation has significantly and positively affected firm performance.
\end{abstract}

Keywords: Mutuality collegiate relation, customer service competence, customer retention program, firm performance.

\section{Introduction}

The problem of this research is still a difference in the research findings on the effect of customer service competence on firm performance. Several studies have found results that a significant relationship between customer service competence on firm performance, while other studies found no effect between competence customer service on firm performance. Chuang and Liao (2010), Liang, Lin and Huang (2012) and Vickery, Jayaram, Droge and Calantone (2003) in their studies found significant influence outcome between customer service competence on firm performance, while research conducted by Fernandes, Mills and Fleury (2005) and Gursoy and Swanger (2007) found that there is no influence between customer service competence on firm performance. The formulation of the research problem is how to develop a new theoretical approach to address the gap between customer service competences on firm performance.

The proposition in this study can be arranged that collegial relationship mutuality is a character transactional relationship that ensures mutual interest between the firm and customer who spirit of mutual benefit based. This factor will potentially improve firm performance. The proposition is constructed from relational interaction, trust, familiarity and similarity strength.
The purpose of this research is to provide an explanation of differences in the relationship customer service competence on firm performance, as well as to track and analyze the concept of collegial relationship mutuality with firm performance. Related to these objectives, it can be specified objectives to be achieved in this research is to empirically examine the factors that effect of customer service competence on firm performance.

While the benefits that can be obtained from this research is to contribute to help drive strategic management research for the development phase when the conceptual model and the theory of measurement has not been well developed, particularly regarding relationships and customer service competence associated with collegial relationship mutuality in improving firm performance. Secondly is to provide quantitative and qualitative analysis to see the best relationships between variables in improving firm performance. Thirdly is to contribute managerial thinking that can be used as consideration in improving corporate performance by linking the stages of the creation process of the customer service competence, collegial relationship mutuality, customer retention program. Finally is to contribute to the business practices in strategic planning framework for more integrated way by considering managerial resources and knowledge. 
Based on the model developed above and the literature review, then a model of empirical research can be presented. For each variables, indicators can be explained as follows. The indicators of variable competence of the transaction on the main service provided to customers are flexible service arrangement, customer value creation, capability of customer service and interactive technology (Dhaliwal, Onita, Poston, \& Zhang 2011; Gronroos, 2011; Klein, Liu, Houn, Chen, \& Jiang 2010; and ten Brummelhuis, Haar, \& van der Lippe 2010). The indicators of variable collegial relationship mutuality are relational interaction, trust, familiarity and similarity strength (Johnsen \& Lee, 2012; Ndubisi, Nasution, Mavondo, \& Matanda 2011; Coulter \& Coulter, 2003).

Variable after sales service competence is the ability to integrate assets, processes, expertise and knowledge owned by the company on additional services provided to the customer after the transaction. It has indicators such as to provide supporting services, interorganizational communication, prosocial service behavior dan interactive voice retailing (Huang, 2011; Paulraj, Lado, \& Chen 2008; Awuah, 2007).

Variable customer retention program can be interpreted as a program of activities that run the company to maintain customer loyalty or continue to consume a product in the form of goods or services produced. It has indicators such as loyalty program membership, personal interaction quality, innovation behavior, harmonious conflict resolution and relationship durability (Sperdin, Grissemann, \& Plank 2012; Pan, Sheng, \& Frank 2012; Vesel \& Zabkar, 2009; and Goo \& Huang, 2008).

Variable firm performance is the level of achievement that the company performed continuously. It has indicators are the amount of financing, the amount of deposits, number of clients/members and the level of profit (Steven, Dong, \& Dresner 2012; Tzempelikos \& Gounaris, 2011; Yee, Yeung, \& Cheng 2010, Chi \& Gursoy, 2009; Ferdinand, 2002).

$H_{l}$ : There is positive and significant correlation between competence of the transaction to collegial relations mutuality

$H_{2}$ : There is positive and significant impact collegial relations between mutuality to firm performance

$H_{3}$ : There is positive and significant correlation between competences of the transaction to customer retention program

$H_{4}$ : There is positive and significant correlation between competences after sales service to collegial relationship mutuality

$H_{5}$ : There is positive and significant correlation between competences after sales service to customer retention program

$H_{6}$ : There is no positive and significant correlation between collegial relationship mutuality to customer retention program

$H_{7}$ : There is positive and significant correlation between customer retention programs to firm performance

$H_{8}$ : There is positive and significant correlation between competence of the transaction to firm performance

$H_{9}$ : There is not a significant difference between competences after sales service to firm performance

\section{Research Method}

Empirical data obtained for this research is obtained directly from the filling list of statements and questions by 105 respondents are obtained from the head of the Islamic micro finance institutions active in East Java. The statements in enclosed questionnaire are prepared by using a scale from 1-10. To obtain interval data is by using techniques agree and disagree scale. On respondents' answers are then given the number 1 (one) to express the opinions of respondents strongly disagree, while the number 10 (ten) to express the opinions of respondents strongly agree. As for the descriptive respondents, this study uses three criteria boxes (three box method), then the range of 9 divided into 3, resulting in a range of three which will be used as the basis for interpretation of the average value, i.e.: 1.00 to $4.00=$ low, 4.01 to $7.00=$ mean and 7.01 to $10.00=$ high. This research analyzed the data used in the analysis technique Partial Least Square (PLS) - Structural Equation Modelling (SEM) Program SmartPLS that allows researchers to test the validity and reliability of research instruments, confirming accuracy of the model, as well as a variable to test the effect of other variables.

\section{Result and Discussion}

Results of this research show that the average value of the interpretation of respondents is high. While to test the validity convergent validity of the instrument by showing that all of the instruments used are valid, and all of the variables used to reliably indicate the composite reliability. Results of this research indicate that there is significant influence of competence of the transaction to collegial relations mutuality, competence of the transaction to customer retention program, after sales service 
competence to collegial relationship mutuality, after sales service competence to customer retention program, customer retention program to firm performance and competence of the transaction to firm performance. It gives a positive value of the parameter coefficient and $t$-statistic value $>t$-table (1.96), whereas collegial relations mutuality to customer retention program not significant effect for the value of $t$-statistic $<t$-table (1.96) and competence after sales service to firm performance coefficient parameters/ negative direction.

The test result of hypothesis one is the better competence of the transaction will be the better collegial relationship mutuality. The test result of hypothesis two is the better collegial relationship mutuality will increase firm performance. The test result of hypothesis three is the better competence of the transaction will be the better customer retention program. The test result of hypothesis four is the better competence after sales service will be the better collegial relationship mutuality. The test result of hypothesis five is the better competence after sales service will be the better customer retention program.

While the test result of hypothesis six is negative relationship can be interpreted that the better collegial relationship mutuality then it will get worse customer retention program. The test result of hypothesis seven is the better the customer retention program will increase firm performance. The test result of hypothesis eight is the better competence of the transaction will be the better firm performance. The test result of hypothesis nine is the better competence after sales service will be the better firm performance.

The results of testing mediation (Sobel test) between the competence of the transactions on the company's performance $p$-value of 0.0083282 , and if $p$ value $<0.05$, it is evident that the variable collegial relationship mutuality is able to mediate between competence of the transaction to firm performance. Similarly to the results of testing mediation (Sobel test) between after sales service competence on company performance $p$-value of 0.0000 , and if $p$-value $<0.05$, the variable customer retention program is able to mediate between after sales service competence to firm performance.

The increase of customer service competence drives firm performance by improving the competence of the transaction. Competence of transaction will improve collegial relations mutuality, and the increase mutuality collegial relations in turn will improve the firm performance. The improved customer service competence drives firm performance can be through the increase of competence of the transaction. Competence of the transaction will increase the customer retention program, with an increase in customer retention programs. Then, in turn it will improve the firm performance. While improving customer service competence to drive company performance by improving the after-sales service competence, the increase of sales service competence will improve collegial relations mutuality, and the increase of collegial relationship mutuality in turn will improve the firm performance. And improving customer service competence to drive firm performance by improving the after-sales service competence, the increase of after sales service competence will improve customer retention program. The increase of customer retention programs will improve the firm performance.

Theoretical implications of these results generally confirm the previous results of research and the concepts that positive effect competence of the transaction to collegial relationship mutuality. Baumard, André, and Sperber (2013) state that competence of company's service excellence mutuality interactions in the built environment of cooperation, in which individuals are able to benefit from such cooperation. While Hana, Kim and Hyun (2011) states that the competence to company's service excellence mutuality interactions in the built environment of cooperation, where individuals can mutually benefit and yield control, choice and punishment from the perspective of a mutuality, where the exchange is a perception among contributions and distributions, mutual aid as the perception of costs and benefits, as a punishment perceptions between losses and compensation. And supported by Johnsen and Lee (2012) which states on the perspective of the customer and supplier relationships in the exploration stage is still vulnerable, at times reflect the behavior and priorities evolve, respectively, while the stable phase may contribute to the mutual and balanced relationship.

For collegial relations mutuality, positive effect on firm performance is supported by the findings of Kohtamaki, Partanen and Möller (2013) which state that the development of interaction and collaboration among network service on the complexity of knowledge-intensive services can create financial gain performance. Additionally Bloemer, Pluymaekers and Odekerken (2012) focus on the role of trust and effective commitment as force energy for the development of a relationship that has had a positive effect on the company performance exports. While Christopher (2012) declares autonomy and collegial practices continue to exist in the culture company at all levels as a significant influence on the company performance.

Competence of the transaction has positive effect to customer retention program. The previous research results confirm the concept. Zalatar (2012) 
states that the competence of service affects to the relative of importance attributed to service quality dimensions, customer expectations, and perceptions of service quality of banks. In addition to the strategies it will enhance the client's perception of the competence of the customer's bank will wake to survive. While Depaire, Wets, and Vanhoof (2012) states that the competence of the company reflected in the compatibility between product performance and customer expectation has a positive influence on the customer's intentions, as well as customer satisfaction on the service will build customer loyalty and survive.

Competence of after-sales service has positive influence on collegial relations mutuality. It is supported by the findings of the study of Chansirisira and Pacharawit (2012) which states that in order to produce a mutually beneficial relationship, the core of service competencies should be developed supporting competence as competence and achievement motivation, teamwork competence, competence service mind and competence development. While Haas, Snehota and Corsaro (2012) states that the value creation of additional competencies as a process of interaction is to identify four features of value creation processes are business relationships, togetherness, and initiatives are balanceed, the value of the interaction, and cognitive and social construction framework used to create value in a business relationship.

After-sales service competence has a positive effect on customer retention programs. The research results confirm the concept of Gupta and Kim (2008) which states that no causal relationship to the competence of support services such as functional and social usefulness, quality systems, pleasure, passion and commitment to significant attitude on customer retention, so as to provide insights for practitioners to retain their customers. It is also supported by the findings of Liou and Tzeng (2007) that uses the service competence in the relationship between the employee service cost, schedule on the board, on-time performance effect on customer satisfaction, and loyalty.

Collegial relations mutuality negatively effects to customer retention program. The result confirms the concept of Polo, Sese and Verhoef (2011) which states that there is a strong effect or influence to competency of services company backed by the trust of customers as a determinant of customer loyalty. But loyalty is less strong when the product is purchased at the regular purchase cycle is relatively short and, if in the long term will support the last customer. It is also supported the findings of Yague, Berne and Mugica (2011) which explores the negative role for variations in customer retention for service. The result is said that a variety of consumer searches a negative effect on customer retention and reduces the impact of management's efforts to improve service quality and customer satisfaction.

Customer retention program has a positive effect on firm performance. It is confirming the concept and the study result of Gerpott, Rams and Schindler (2001) which states that the mutually beneficial relationship will be able to generate customer retention. Besides the general focus on profitability as well as external constraints on the termination of the relationship are found to significantly affect the company's relationship termination competence. It is also supported by the findings of Gong, Yi, and Nataraajan (2011) which states that the behavior support customer participation, customer habitual behavior, similarity, preference, satisfaction of employees will be able to create customer retention, thereby increasing the company performance.

Competence of the transaction has a positive effect on firm performance, and the result of the study confirms the concept of Lin, Su and Chien (2006) which uses model-based customer relationship management, in which the model presented can facilitate the identification of important factors that have a significant impact on business performance. The result shows that to provide products and services for customer transactions as well as best practices for sharing information internally may have benefits for appropriate action by market share, repeat purchases, and customer retention in order to achieve superior performance, while the complaint information from customers and various internal best practices information can have benefits for market leader and cost savings that will improve the company's performance.

After sales service competence has no significant effect on firm performance. It could not confirm the concept and research result of Wang, Lo and Yang (2004), which explores the 248 respondents/ high-tech enterprises in Beijing, Tianjin and Shenzhen of China. The finding that competence support services consisting of marketing competence, technological competence and overall integrative competence can be positive and significant effect on company performance.

Evaluation of empirical research on the model as a whole cannot be said to be the best fit model but it is just adequate. This is because the values of the reference and the test of the suitability criteria or statistical models that use an evaluation model of the measurement and evaluation of the structural model are diverse, where there are unmet and there are only approaching the reference value or a cut of value that is approached/ marginal. For that level of ability in explaining the relationship between variables is still 
not optimal. Statistically, it explains the ability of the variables that effect (antecedent) of the consequent variable. It is said robust if its value closes to unity. Based on the result of statistical testing is known that the value of $R^{2}$ for collegial relationship mutuality of 0.26 . It means that only the variable competence of the transaction and competence after sales service are able to account for the variation in the variable collegial relationship mutuality by $26 \%$ while $74 \%$ is explained by other variables that are not included in the model. This may imply that there are many other variables that need to be included in the model because of the ability to explain these variables is still far from perfect.

\section{Conclusions and Implications}

The study shows that seven of nine hypotheses are accepted while the remaining two hypotheses are rejected using the structural equation modeling procedure. This results conclude that mutuality collegiate relation has significantly and positively affected firm performance. Next research should be able to better explain the effect of collegial relationship mutuality on customer retention program by adding indicators on each of the variables or adding to the respondents as well as respondents who use industry background so that the model can produce a suitability and better research model. It should be able to better explain the effect of collegial relationship mutuality in improving firm performance by using analytical tools that are better suited to the large sample size and indicator for example by using AMOS (Analysis of Moment Structure).

\section{References}

Awuah, G. B. (2007). A professional services firm's competence development. Industrial Marketing Management, 36(8), 1068-1081.

Baumard, N., André, J. B., \& Sperber, D. (2013). A mutuality approach to morality: The evolution of fairness by partner choice. Behavioral and Brain Sciences, 36, 59-122.

Bloemer, J., Pluymaekers, M., \& Odekerken. A. (2012). Trust and affective commitment as energizing forces for export performance. International Business Review, 22, 363-380.

Chansirisira \& Pacharawit (2012). Articles study of core competency elements and factors affecting performance efficiency of government teachers in Northeastern Thailand. International Education Studies, 5(6), 161-167.

Chi, C. G \& Gursoy, D. (2009). Employee satisfaction, customer satisfaction, and financial perfor- mance: An empirical examination. International Journal of Hospitality Management, 28, 245253.

Christopher, J. (2012). Tension between the corporate and collegial cultures of Australian public universities: The current status. Critical Perspectives on Accounting, 23, 556-571.

Chuang, C. H. \& Liao, H. (2010). Strategic human resource management in service context: Taking care of business by taking care of employees and customer. Personnel Psychology, 63, 153-196.

Coulter, K. S. \& Coulter, R. A. (2003). The effects of industry knowledge on the development of trust in service relationships. International Journal of Research in Marketing, 20(1), 31-43.

Depaire, B., Wets, G., \& Vanhoof, K. (2012). A decision support tool for evaluating customer intentions. Expert Systems with Applications, 39, 903 -910 .

Dhaliwal, J., Onita, C. G., Poston, R., \& Zhang, X. P. (2011). Alignment within the software development unit: Assessing structural and relational dimensions between developers and testers. Journal of Strategic Information Systems, 20, 323342.

Ferdinand, A. (2002). Structural equation modelling dalam penelitian manajemen. Semarang: Badan Penerbit Universitas Diponegoro.

Fernandes, B. H., Mills, J. F., \& Fleury, M. T. L. (2005). Resources that drive performance: An empirical investigation. International Journal of Productivity and Performance Management, 54, 340-354.

Gerpott, T. J., Rams, W., \& Schindler, A. (2001). Customer retention, loyalty, and satisfaction in the German mobile cellular telecommunications market. Telecommunications Policy, 25, 249269.

Gong, T., Yi, Y., \& Nataraajan, R. (2011). Customer participation and citizenship behavioral influences on employee performance, satisfaction, commitment, and turnover intention. Journal of Business Research, 64, 87-95.

Goo, J. \& Huang, C. D. (2008). Facilitating relational governance through service level agreements in IT outsourcing: An application of the commitment trust theory. Decision Support Systems Journal, 46, 216-232.

Gronroos, C. (2011). A service perspective on business relationships: The value creation, interaction and marketing interface. Industrial Marketing Management Journal, 40, 240-247.

Gupta, S. \& Kim, H. W. (2008). Linking structural equation modeling to Bayesian networks: Decision support for customer retention in virtual communities. European Journal of Operational Research, 190, 818-833. 
Gursoy, D. \& Swanger, N. (2007). Performance enhancing internal strategic factors and competencies: Impacts on financial success. Hospitality Management, 26, 213-227.

Haas, A., Snehota, I., \& Corsaro, D. (2012). Creating value in business relationships: The role of sales. Industrial Marketing Management, 41, 94-105.

Hana, H., Kim, W., \& Hyun, S. S. (2011). Switching intention model development: Role of service performances, customer satisfaction, and switching barriers in the hotel industry. International Journal of Hospitality Management, 30, 619629.

Huang, C. S. (2011). Some insights into customer orientation: An investigation of salespeople in Taiwan. The International Journal of Human Resource Management, 22(12), 2647-2663.

Johnsen, R. E. \& Lee, C. J. (2012). Asymmetric customer-supplier relationship development in Taiwanese electronicsfirms. Industrial Marketing Management, 41, 692-705.

Klein, G., Liu, J. Y., Houn, H., Chen, G., \& Jiang, J. J. (2010). Task completion competency and project management performance: The influence of control and user contribution. International Journal of Project Management, 28, 220-227.

Kohtamaki, M., Partanen, J., \& Möller, K. (2013). Making a profit with R\&D services-The critical role of relational capital. Industrial Marketing Management, 42, 71-81.

Liang, C. J., Lin, Y. L., \& Huang, H. F. (2012). Effect of core competence on organizational performance in an airport shopping center. Journal of Air Transport Management, 11(5), 11-24.

Lin, Y., Su, H. Y., \& Chien, S. (2006). A knowledge enabled procedure for customer relationship management. Industrial Marketing Management, 35, 446- 456 .

Liou, J. J. H. \& Tzeng, G. H. (2007). A non additive model for evaluating airline service quality. Journal of Air Transport Management, 13, 131138.

Ndubisi, N. O., Nasution, H. N., Mavondo, F. T., \& Matanda, M. J. (2011). Entrepreneurship: Its relationship with market orientation and learning orientation and as antecedents to innovation and customer value. Industrial Marketing Management Journal, 40, 336-345.

Pan, Y., Sheng, S., \& Frank T. X. (2012). Antecedents of customer loyalty: An empirical synthesis and reexamination. Journal of Retailing and Consumer Services, 19, 150-158.

Paulraj, A., Lado, A. A., \& Chen, I. J. (2008). Interorganizational communication as a relational competency: Antecedents and performance outcomes in collaborative buyer-supplier relation- ships Journal of Operations Management, 26, 45-64.

Polo, Y., Sese, F. J., \& Verhoef, P. C. (2011). The effect of pricing and advertising on customer retention in a liberalizing market. Journal of Interactive Marketing, 25, 201-214.

Sperdin, A. B., Grissemann, U., \& Plank, A. (2012). Enhancing business performance of hotels: The role of innovation and customer orientation. International Journal of Hospitality Management, 10.

Steven, A. B., Dong, Y., \& Dresner, M. (2012). Linkages between customer service, customer satisfaction and performance in the airline industry: Investigation of non-linearities and moderating effects. Transportation Research Part E, 48, 743-754.

ten Brummelhuis, L. L., Haar, J. M., \& van der Lippe, T. (2010). Collegiality under pressure: The effects of family demands and flexible work arrangements in the Netherlands. The International Journal of Human Resource Management, 21(15), 2831-2847.

Tzempelikos, N. \& Gounaris, S. (2011). Key account management orientation and company performance: does relationship quality matter?. American Marketing Association/Winter, 269-277.

Vesel, P. \& Zabkar, V. (2009). Managing customer loyalty through the mediating role of satisfaction in the DIY retail loyalty program. Journal of Retailing and Consumer Services, 16, 396-406.

Vickery, S. K., Jayaram, J., Droge, C., \& Calantone, R. (2003). The effects of an integrative supply chain strategy on customer service and financial performance: An analysis of direct versus indirect relationships. Journal of Operations Management, 21, 523-539.

Wang, Y., Lo, H. P., \& Yang, Y. (2004). The constituents of core competencies and firm performance: Evidence from high-technology firms in china. Journal English Technology Management, 21, 249-280.

Yague, M. J., Berne, C., \& Mugica, J. M. (2001). The effect of variety-seeking on customer retention in services. Journal of Retailing and Consumer Services, 8, 335-345.

Yee, R. W. Y., Yeung, A. C. L., \& Cheng, T. C. E. (2010). An empirical study of employee loyalty, service quality and firm performance in the service industry. International Journal Production Economics, 24, 109-120.

Zalatar, W. F. (2012). Quantifying customers gender effects on service quality perceptions of Philippine commercial banks. Procedia Social and Behavioral Sciences, 57, 268-274. 